\title{
Formation and Evolution of Chain-Propagating Species Upon Ethylene Polymerization with Neutral Salicylaldiminato Nickel(II) Catalysts
}

\author{
Igor E. Soshnikov, ${ }^{[a]}$ Nina V. Semikolenova, ${ }^{[a]}$ Vladimir A. Zakharov, ${ }^{[a]}$ \\ Heiko M. Möller, ${ }^{[b]}$ Franz Ölscher, ${ }^{[b]}$ Anna Osichow, ${ }^{[b]}$ Inigo Göttker-Schnettmann, ${ }^{[b]}$ \\ Stefan Mecking, ${ }^{*[b]}$ Evgenii P. Talsi, ${ }^{[a]}$ and Konstantin P. Bryliakov*[a]
}

\begin{abstract}
Formation of Ni-polymeryl propagating species upon the interaction of three salicylaldiminato nickel(II) complexes of the type [(N,O)Ni$\left.\left(\mathrm{CH}_{3}\right)(\mathrm{Py})\right] \quad$ (where $(\mathrm{N}, \mathrm{O})=$ salicylaldimine ligands, $\mathrm{Py}=$ pyridine) with ethylene $\left(\mathrm{C}_{2} \mathrm{H}_{4} / \mathrm{Ni}=10: 30\right)$ has been studied by ${ }^{1} \mathrm{H}$ and ${ }^{13} \mathrm{C}$ NMR spectroscopy. Typically, the ethylene/catalyst mixtures in $\left[D_{8}\right]$ toluene were stored for short periods of time at $+60^{\circ} \mathrm{C}$ to generate the $[(\mathrm{N}, \mathrm{O}) \mathrm{Ni}($ polymeryl $)]$ species, then quickly cooled, and the NMR measurements were conducted at $-20^{\circ} \mathrm{C}$. At that temperature, the $[(\mathrm{N}, \mathrm{O}) \mathrm{Ni}($ polymeryl)] species are stable for days; dif-
\end{abstract}

fusion ${ }^{1} \mathrm{H}$ NMR measurements provide an estimate of the average length of polymeryl chain (polymeryl= $\left.\left(\mathrm{C}_{2} \mathrm{H}_{4}\right)_{n} \mathrm{H}, n=6-18\right)$. At high ethylene consumptions, the $[(\mathrm{N}, \mathrm{O}) \mathrm{Ni}($ polymer$\mathrm{yl})]$ intermediates decline, releasing free polymer chains and yielding $[(\mathrm{N}, \mathrm{O}) \mathrm{Ni}(\mathrm{Et})(\mathrm{Py})]$ species, which also further decompose to form the ultimate catalyst degradation product, a

\section{Introduction}

Since the discovery of $\alpha$-diimine nickel(II) catalysts, ${ }^{[1]}$ neutral nickel(II) polymerization catalysts have attracted undiminished interest due to their tolerance toward polar reagents, as well as the controllable degree of polymer branching and $\alpha$-olefin enchainment. ${ }^{[2]}$ Some single-component nickel(II) catalysts exhibit polymerization activity without any co-catalyst (i.e., without methylalumoxane or boron compounds) ${ }^{[3]}$ which is of particular value when designing polymerizations of polar monomers or for the synthesis of latexes by direct olefin polymerization in aqueous media. ${ }^{[4]}$

[a] Dr. I. E. Soshnikov, Dr. N. V. Semikolenova, Prof. V. A. Zakharov, Prof. Dr. E. P. Talsi, Prof. Dr. K. P. Bryliakov

Institute of Catalysis, Pr. Lavrentieva 5 630090 Novosibirsk (Russian Federation) Fax: (+7)383-3308056 E-mail: bryliako@catalysis.ru

[b] Prof. Dr. H. M. Möller, F. Ölscher, A. Osichow, Dr. I. Göttker-Schnettmann, Prof. Dr. S. Mecking University of Konstanz, Chair of Chemical Material Science Department of Chemistry, Universitätstrasse 10 78457 Konstanz (Germany)

Fax: $(+49) 7531-885152$

E-mail: stefan.mecking@uni-konstanz.de paramagnetic $\left[(\mathrm{N}, \mathrm{O})_{2} \mathrm{Ni}(\mathrm{Py})\right]$ complex. In $\left[(\mathrm{N}, \mathrm{O})_{2} \mathrm{Ni}(\mathrm{Py})\right]$, the pyridine ligand is labile (with activation energy for its dissociation of $(12.3 \pm 0.5) \mathrm{kcal} \mathrm{mol}^{-1}$, $\Delta H^{\neq}{ }_{298}=(11.7 \pm 0.5) \mathrm{kcalmol}^{-1}, \Delta S^{\neq}{ }_{298}$ $\left.=(-7 \pm 1) \mathrm{cal} \mathrm{K}^{-1} \mathrm{~mol}^{-1}\right)$. Upon the addition of nonpolar solvent (pentane), the pyridine ligand is lost completely to yield the crystals of diamagnetic $\left[(\mathrm{N}, \mathrm{O})_{2} \mathrm{Ni}\right]$ complex. NMR spectroscopic analysis of the polyethylenes formed suggests that the evolution of chainpropagating species ends up with formation of polyethylene with predominately internal and terminal vinylene groups rather than vinyl groups.
Mechanistic studies of neutral $\mathrm{Ni}^{\mathrm{II}}$ polymerization catalysts have so far been rather rare. Jenkins and Brookhart reported a ${ }^{1} \mathrm{H}$ NMR spectroscopic investigation of a $\mathrm{Ni}^{\mathrm{II}}$ anilinotropone system. In their study the kinetic parameters of the first insertion of ethylene into the $\mathrm{Ni}$-aryl bond of $\left[(\mathrm{N}, \mathrm{O}) \mathrm{Ni}(\mathrm{Ph})\left(\mathrm{PPh}_{3}\right)\right]$ and of the second insertion of ethylene into the $\mathrm{Ni}$-alkyl bond of $\left[(\mathrm{N}, \mathrm{O}) \mathrm{Ni}\left(\mathrm{CH}_{2} \mathrm{CH}_{2} \mathrm{Ph}\right)\left(\mathrm{PPh}_{3}\right)\right]$ were evaluated from the NMR data. ${ }^{[3 \mathrm{~h}]}$ Grubbs with coworkers studied the interaction of a $\left[(\mathrm{N}, \mathrm{O}) \mathrm{Ni}(\mathrm{Ph})\left(\mathrm{PPh}_{3}\right)\right]$ type catalyst with methyl acrylate. ${ }^{\left[{ }^{4 j]}\right.}$ Mecking and co-workers studied the dimerization of ethylene to butenes over $\mathrm{Ni}^{\mathrm{II}}$ salycilaldiminato complex of the type $\left[(\mathrm{N}, \mathrm{O}) \mathrm{Ni}\left(\mathrm{CH}_{3}\right)-\right.$ (DMSO)] in dimethylsulfoxide and documented the formation of $\left[(\mathrm{N}, \mathrm{O}) \mathrm{Ni}\left(\mathrm{CH}_{2} \mathrm{CH}_{3}\right)(\mathrm{DMSO})\right]$ intermediate upon the interaction of the starting catalyst with ethylene, accompanied by the formation of propene. ${ }^{[3]]}$ In a subsequent publication, the insertion of polar vinyl monomers into the $\left[(\mathrm{N}, \mathrm{O}) \mathrm{Ni}\left(\mathrm{CH}_{2} \mathrm{CH}_{3}\right)(\mathrm{DMSO})\right]$ and $\left[(\mathrm{N}, \mathrm{O}) \mathrm{Ni}(\mathrm{H})\left(\mathrm{PMe}_{3}\right)\right]$ precatalysts was investigated. ${ }^{[3 \mathrm{k}]}$ More recently, Delferro and Marks with co-workers have reported a bimetallic $\mathrm{Ni}^{\mathrm{II}}$ catalyst and discussed its deactivation pathways. ${ }^{[2 q]}$ In none of those mechanistic studies, however, were the true catalytically active sites (Ni-polymeryl chain-propagating species) detected spectroscopically and nor has their evolution in the course of polymerization been traced.

This work focused on direct spectroscopic monitoring of the interaction of three $\mathrm{Ni}^{\mathrm{II}}$ pre-catalysts of the type 
$\left[(\mathrm{N}, \mathrm{O}) \mathrm{Ni}\left(\mathrm{CH}_{3}\right)(\mathrm{Py})\right]$ with ethylene, in an effort to better understand the processes occurring during the chain propagation and termination (and also catalyst deactivation), and to assess the nature of chain-carrying intermediates. Differences in the behavior of active species, caused by different salicylaldimine ligand substituents, are discussed. The size of the Ni-polymeryl intermediates has been estimated by diffusion NMR spectroscopic techniques. Furthermore, the major chain termination pathway has been ascertained, and the catalyst deactivation has been scrutinized. The ultimate product of catalyst degradation $\left[(\mathrm{N}, \mathrm{O})_{2} \mathrm{Ni}\right]$ has been isolated from the reaction media and identified by X-ray crystallography.

\section{Results and Discussion}

All starting catalysts 1-3 (Scheme 1) exhibit ${ }^{1} \mathrm{H}$ and ${ }^{13} \mathrm{C}$ NMR spectra typical for diamagnetic $\mathrm{Ni}^{\mathrm{II}}$ complexes (see the Supporting Information). The $\mathrm{Ni}-\mathrm{CH}_{3} \mathrm{NMR}$ signals are found in the range of $\delta=-0.6$ to $-1.0 \mathrm{ppm}$ (in
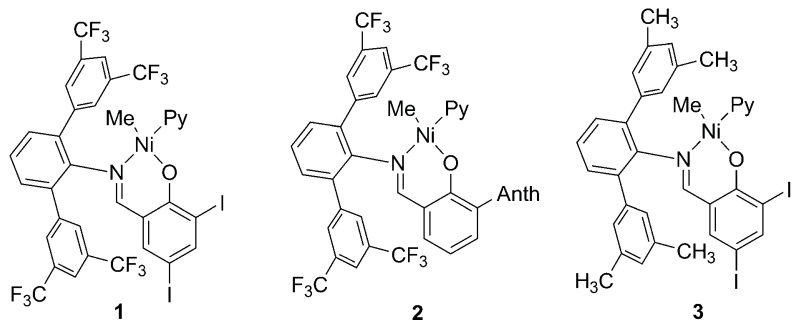

Scheme 1. Catalysts 1-3 considered in this study. Anth $=9$-anthryl.

$\left[\mathrm{D}_{8}\right]$ toluene), depending on the catalyst and on the temperature. In $\left[\mathrm{D}_{8}\right]$ toluene solution, all catalysts are stable at room temperature. However, the injection of ethylene into the catalyst solutions at room and higher temperatures caused rapid chemical reactions that complicated NMR-based characterization. Therefore, the following experimental technique was used. Ethylene was injected into the NMR tube containing the catalyst solution at reduced temperature (cooled in acetone/liquid $\mathrm{N}_{2}$ ), and the sample was placed in a thermostated bath at $+60^{\circ} \mathrm{C}$ for short periods of time $(2$ or $3 \mathrm{~min}$ ) to trigger the formation of [(N,O)Ni(polymeryl)] species. The sample was then quickly cooled with liquid $\mathrm{N}_{2}$, and placed into the NMR probe maintained at $-20^{\circ} \mathrm{C}$, and the measurements were conducted at that temperature.

After storing for $2 \mathrm{~min}$ at $+60^{\circ} \mathrm{C}$, formation of new nickel-alkyl species 1a was detected by the appearance of new resonances in the range of +0.8 to $-1.0 \mathrm{ppm}$ (Figure 1). The most upfield resonance of $\mathbf{1 a}(\delta=$ $-0.19 \mathrm{ppm}$ ) is close to the $\mathrm{Ni}-\mathrm{CH}_{3}$ peak in $\mathbf{1}$ and, based on literature data, ${ }^{[1 \mathrm{c}, 2 \mathrm{r}, 3 \mathrm{i}]}$ can be assigned to the protons of the $\mathrm{Ni}-\mathrm{CH}_{2}-\mathrm{CH}_{2}$ - methylene group of the $\mathrm{Ni}$-polymeryl species formed through ethylene insertion into the nickel-methyl bond of catalyst 1a. ${ }^{1} \mathrm{H}$ COSY spectrum (see Figure S1 in
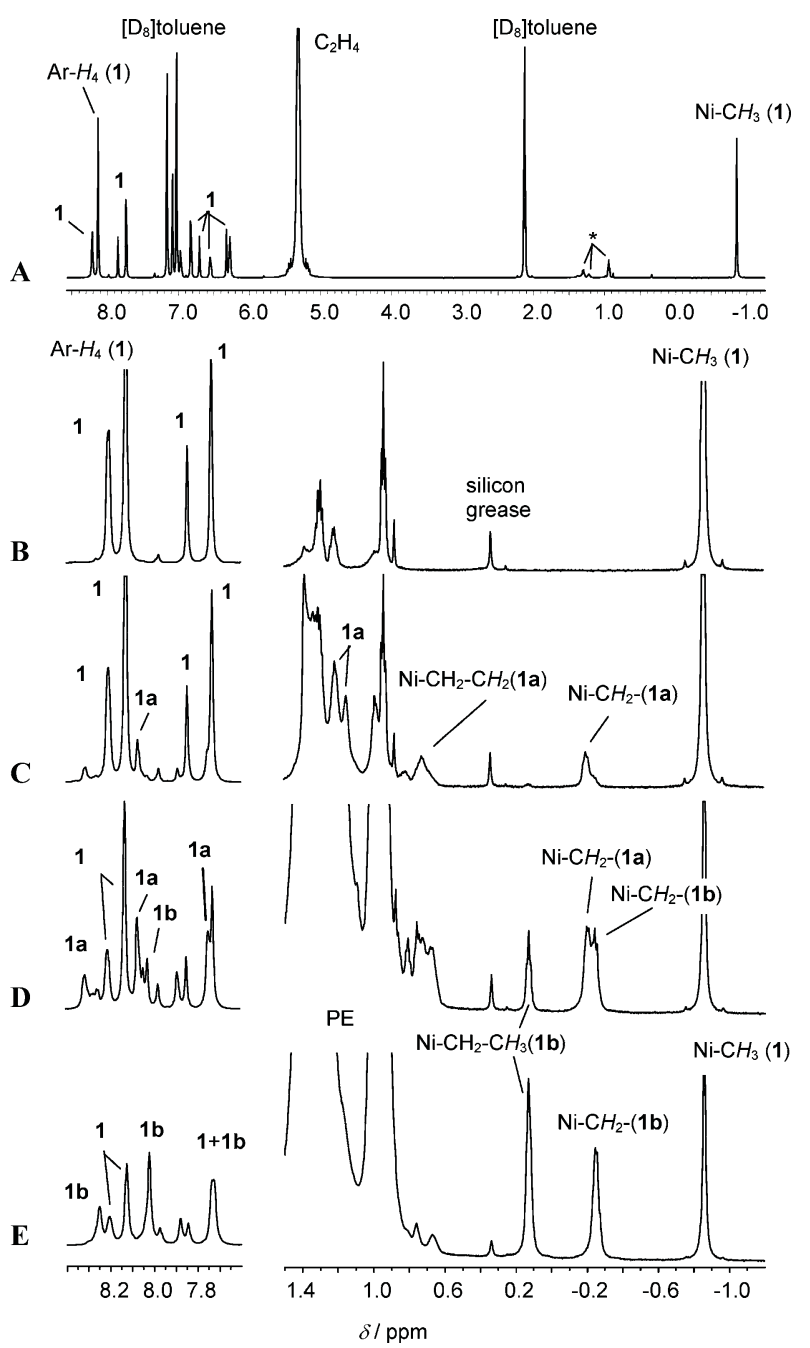

Figure 1. ${ }^{1} \mathrm{H}$ NMR spectra $\left(\left[\mathrm{D}_{8}\right]\right.$ toluene, $\left.-20^{\circ} \mathrm{C}\right)$ of a $0.012 \mathrm{~m}$ solution of catalyst 1 after the injection of 30 equiv of $\mathrm{C}_{2} \mathrm{H}_{4}$ : A) full spectrum and $\mathrm{B}$ ) regions of $\delta=8.4$ to 7.6 and 1.5 to $-1.2 \mathrm{ppm}$; the same sample after storing for C) $2 \mathrm{~min}$, D) $22 \mathrm{~min}$, and E) $51 \mathrm{~min}$ at $+60^{\circ} \mathrm{C}$. The admixture (grease, pentane) in $\left[\mathrm{D}_{8}\right]$ toluene is marked by an asterisk.

the Supporting Information) reveals direct spin-spin coupling between the $\mathrm{Ni}-\mathrm{CH}_{2}-\mathrm{CH}_{2-}$ protons at $\delta=-0.19 \mathrm{ppm}$ and those at $\delta=0.73 \mathrm{ppm}$, which could be assigned to the adjacent $\mathrm{Ni}-\mathrm{CH}_{2}-\mathrm{CH}_{2}$ - methylene group of intermediate $\mathbf{1 a}$. At the same time, a ${ }^{1} \mathrm{H}$ TOCSY spectrum shows that protons of the nickel-bound methylene group $\mathrm{Ni}-\mathrm{CH}_{2}-\mathrm{CH}_{2}$ - correlate with protons of at least three remote methylene groups of the same molecule (see Figure S2 in the Supporting Information), thus confirming that $\mathbf{1} \mathbf{a}$ is indeed a "Nipolymeryl" species rather than Ni-propyl or Ni-ethyl products resulting from either a single ethylene insertion or from a single insertion followed by propene elimination and ethylene reinsertion into the resulting nickel hydride species. ${ }^{[5]}$

In the ${ }^{13} \mathrm{C}$ NMR spectrum, resonances of the corresponding $\mathrm{Ni}-\mathrm{CH}_{2}-\mathrm{CH}_{2}-$ and $\mathrm{Ni}-\mathrm{CH}_{2}-\mathrm{CH}_{2}-$ carbon atoms were found at $\delta=15.34$ and $31.94 \mathrm{ppm}$, respectively (Figure 2, Table 1; to facilitate the ${ }^{13} \mathrm{CNMR}$ measurements, $\left[{ }^{13} \mathrm{C}_{2}\right]$ ethylene was used as the monomer). At the early 

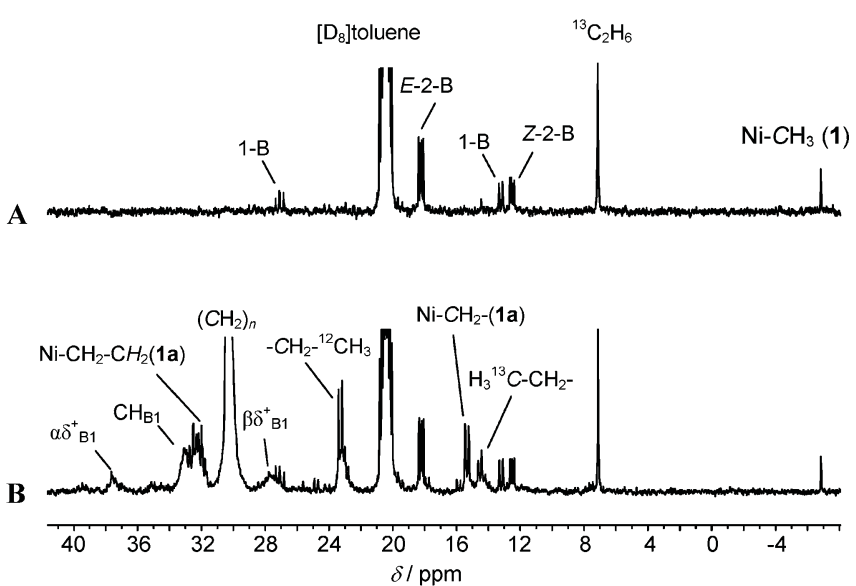

Figure $2 .{ }^{13} \mathrm{C}\left\{{ }^{1} \mathrm{H}\right\}$ NMR spectra $\left(\left[\mathrm{D}_{8}\right]\right.$ toluene, $\left.-20^{\circ} \mathrm{C}\right)$ of a $0.012 \mathrm{~m}$ solution of catalyst $1 \mathrm{~A}$ ) after the injection of 30 equiv of ${ }^{13} \mathrm{C}_{2} \mathrm{H}_{4}$ and $\mathrm{B}$ ) the same sample after storing for $3 \mathrm{~min}$ at $+60^{\circ} \mathrm{C}$. Minor impurities originally present in ${ }^{13} \mathrm{C}_{2} \mathrm{H}_{4}$, that is, ${ }^{13} \mathrm{C}$-enriched ethane, 1-butene, cis-2-butene, and trans-2-butene, are marked as ${ }^{13} \mathrm{C}_{2} \mathrm{H}_{6}, 1-\mathrm{B}, Z$-2-B, and $E$-2-B, respective$1 \mathrm{y}^{[7]}$

stages of interaction $\left(2-5 \mathrm{~min}\right.$ at $\left.+60^{\circ} \mathrm{C}\right)$, only very small NMR signals assignable to unsaturated products of ethylene oligomerization were observed in the ${ }^{1} \mathrm{H}$ and ${ }^{13} \mathrm{C}$ NMR spectra, so the spectrum in Figure $2 \mathrm{~B}$ mostly represents the alkyl part of the Ni- $\left({ }^{13} \mathrm{CH}_{2}{ }^{13} \mathrm{CH}_{2}\right)_{n}{ }^{-12} \mathrm{CH}_{3}$ chain-carrying species $\mathbf{1} \mathbf{a}^{[6]}$

The assignment of ${ }^{13} \mathrm{C}$ and ${ }^{1} \mathrm{H}$ NMR peaks was confirmed by $2 \mathrm{D}$ heteronuclear correlation spectra (see Figure $\mathrm{S} 3$ in the Supporting Information). We note that even at this early stage of polymerization, the existence of chain walking is evidenced by the presence of Me branches (marked as B1 in Figure 2). ${ }^{[7]}$

Further storage of the chain propagating species $\mathbf{1 a}$ in the presence of ethylene at $+60^{\circ} \mathrm{C}$ results in the appearance of intense PE signals at $\delta=1.3\left(-\mathrm{CH}_{2}^{-}\right)$and $0.9\left(-\mathrm{CH}_{3}\right) \mathrm{ppm}$ (see Figure $1 \mathrm{D}$ and $\mathrm{E}$ ). At the same time, peaks of 1a decline, whereas those of a new complex $1 \mathbf{b}$ increase (Figure $1 \mathrm{D}$ and E). ${ }^{1} \mathrm{H}$ and ${ }^{13} \mathrm{C}$ NMR parameters of $\mathbf{1 b}$ (Table 1 ) as well as the fact that $\mathbf{1 b}$ prevails when most ethylene is consumed (Scheme 2), allows its assignment to a Ni-Et complex. Compound $\mathbf{1 b}$ is relatively stable and partially survives in solution even after storing the sample for days at room temperature or for hours at $+60^{\circ} \mathrm{C}$. One possible reason for this high stability is the presence of equatorially coordinated pyridine in the coordination sphere of $\mathrm{Ni}$, which hampers $\beta$-hydride elimination, so that $\mathbf{1 b}$ could be reasonably formulated as $[(\mathrm{N}, \mathrm{O}) \mathrm{Ni}(\mathrm{Et})(\mathrm{Py})]$. Although rather stable, the latter nevertheless gradually declines upon prolonged storage for hours at $+60^{\circ} \mathrm{C}$ or for days at room temperature, yielding new paramagnetic nickel species (see below).

Complex 2 reacts with ethylene in a similar way, yielding species [(N,O)Ni(polymeryl)] (2a) and [(N,O)Ni(Et)(Py)] (2b) (Table 1). Their NMR spectra are reported in the Supporting Information (Figure S4-S6).

In contrast, the $[(\mathrm{N}, \mathrm{O}) \mathrm{Ni}($ polymeryl $)]$ intermediate has not been detected for catalyst 3. Apparently, 3 is more prone to $\beta$-hydride elimination, so that after storing the sample $3 / \mathrm{C}_{2} \mathrm{H}_{4}$ for $3 \mathrm{~min}$ at $60^{\circ} \mathrm{C}$, the majority of $\mathbf{3}$ undergoes ethylene insertion with subsequent fast formation of polymer and $[(\mathrm{N}, \mathrm{O}) \mathrm{Ni}(\mathrm{Et})(\mathrm{Py})](\mathbf{3 b})$; some residual 3 can also be detected. At the same time, intense NMR signals of olefinic groups (cis- and trans-vinylene groups) of free polymer chains are observed (Figure S7). This result is in qualitative agreement with the report that catalyst $\mathbf{3}$ yields a much shorter (and more densely branched) PE than with $\mathbf{1}$ and $\mathbf{2}^{[21]}$ The most likely reason for the different catalytic behavior of complexes $\mathbf{1}$ and $\mathbf{2}$, on the one hand, and $\mathbf{3}$ on the other hand, is the presence of trifluoromethyl groups near the active center in the chain-propagating species $\mathbf{1 a}$

Table 1. Selected NMR parameters $\left(-20^{\circ} \mathrm{C},\left[\mathrm{D}_{8}\right]\right.$ toluene $)$ of $\mathrm{Ni}^{\mathrm{II}}$-alkyl species considered in this study.

\begin{tabular}{|c|c|c|c|c|c|c|c|c|c|}
\hline Species & $\begin{array}{l}\mathrm{Ni}-\mathrm{CH}_{2-} \\
\delta{ }^{1} \mathrm{H} \\
\left({ }^{1} J(\mathrm{C}, \mathrm{H})\right)\end{array}$ & $\begin{array}{l}\delta{ }^{13} \mathrm{C} \\
\left({ }^{1} J(\mathrm{C}, \mathrm{C})\right)\end{array}$ & $\begin{array}{l}\mathrm{Ni}-\mathrm{Cl} \\
\delta{ }^{1} \mathrm{H}\end{array}$ & $\begin{array}{l}\mathrm{H}_{2^{-}} \\
\delta{ }^{13} \mathrm{C} \\
\left({ }^{1} J(\mathrm{C}, \mathrm{C})\right)\end{array}$ & $\begin{array}{l}\mathrm{Ni}-\mathrm{CH}_{2}-\mathrm{CH}_{3} \\
\delta{ }^{1} \mathrm{H} \\
\left({ }^{1} J(\mathrm{C}, \mathrm{H})\right)\end{array}$ & $\begin{array}{l}\delta{ }^{13} \mathrm{C} \\
\left({ }^{1} J(\mathrm{C}, \mathrm{C})\right)\end{array}$ & $\begin{array}{l}\mathrm{Ar}-\mathrm{H}_{4} \\
\delta{ }^{1} \mathrm{H}\end{array}$ & $\begin{array}{l}\text { Other } \\
\delta{ }^{1} \mathrm{H}\end{array}$ & $\delta{ }^{13} \mathrm{C}$ \\
\hline 1 & - & - & - & - & - & - & 8.13 & $\begin{array}{l}-0.86 \\
\left(\mathrm{Ni}-\mathrm{CH}_{3}\right)\end{array}$ & $\begin{array}{l}-6.99 \\
\left(\mathrm{Ni}-\mathrm{CH}_{3}\right)\end{array}$ \\
\hline $1 \mathbf{a}$ & $\begin{array}{l}-0.19 \\
(126 \mathrm{~Hz})\end{array}$ & $\begin{array}{l}15.34 \\
(\mathrm{~d}, 32.3 \mathrm{~Hz})\end{array}$ & 0.73 & $\begin{array}{l}31.94 \\
(\mathrm{t}, 32 \mathrm{~Hz})\end{array}$ & - & - & 8.07 & $\begin{array}{l}1.21,1.47 \\
\left(-\mathrm{CH}_{2^{-}}\right)\end{array}$ & $\begin{array}{l}30.6 \\
\left(-\mathrm{CH}_{2^{-}}\right)\end{array}$ \\
\hline $1 \mathbf{b}$ & $\begin{array}{l}-0.25 \\
(126 \mathrm{~Hz})\end{array}$ & $\begin{array}{l}7.53 \\
(\mathrm{~d}, 33.5 \mathrm{~Hz})\end{array}$ & - & - & $\begin{array}{l}0.13 \\
(124.5 \mathrm{~Hz})\end{array}$ & $\begin{array}{l}15.85 \\
(\mathrm{~d}, 33.5 \mathrm{~Hz})\end{array}$ & 8.02 & & \\
\hline 2 & - & - & - & - & - & - & 8.28 & $\begin{array}{l}-1.08 \\
\left(\mathrm{Ni}-\mathrm{CH}_{3}\right)\end{array}$ & $\begin{array}{l}-7.47 \\
\left(\mathrm{Ni}-\mathrm{CH}_{3}\right)\end{array}$ \\
\hline $2 \mathbf{a}$ & -0.44 & $\begin{array}{l}14.40 \\
(\mathrm{~d}, 32.8 \mathrm{~Hz})\end{array}$ & 0.48 & $\begin{array}{l}31.83 \\
(\mathrm{t}, 33 \mathrm{~Hz})\end{array}$ & - & - & 8.23 & $\begin{array}{l}1.00,1.22 \\
\left(-\mathrm{CH}_{2^{-}}\right)\end{array}$ & $\begin{array}{l}30.5 \\
\left(-\mathrm{CH}_{2^{-}}\right)\end{array}$ \\
\hline $2 \mathbf{b}$ & -0.48 & $\begin{array}{l}6.69 \\
(\mathrm{~d}, 33.3 \mathrm{~Hz})\end{array}$ & - & - & 0.01 & $\begin{array}{l}15.85 \\
(\mathrm{~d}, 33.3 \mathrm{~Hz})\end{array}$ & 8.22 & & \\
\hline 3 & - & - & - & - & - & - & 7.37 & $\begin{array}{l}-0.59 \\
\left(\mathrm{Ni}-\mathrm{CH}_{3}\right) \\
2.26 \\
\left(\mathrm{Ar}-\left(\mathrm{CH}_{3}\right)_{4}\right)\end{array}$ & $\begin{array}{l}-7.18 \\
\left(\mathrm{Ni}-\mathrm{CH}_{3}\right)\end{array}$ \\
\hline $3 \mathbf{b}$ & 0.06 & $\begin{array}{l}7.08 \\
(\mathrm{~d}, 33.2 \mathrm{~Hz})\end{array}$ & - & - & 0.33 & $\begin{array}{l}16.67 \\
(\mathrm{~d}, 33.2 \mathrm{~Hz})\end{array}$ & 7.31 & $\begin{array}{l}2.26 \\
\left(\mathrm{Ar}-\left(\mathrm{CH}_{3}\right)_{4}\right)\end{array}$ & \\
\hline
\end{tabular}




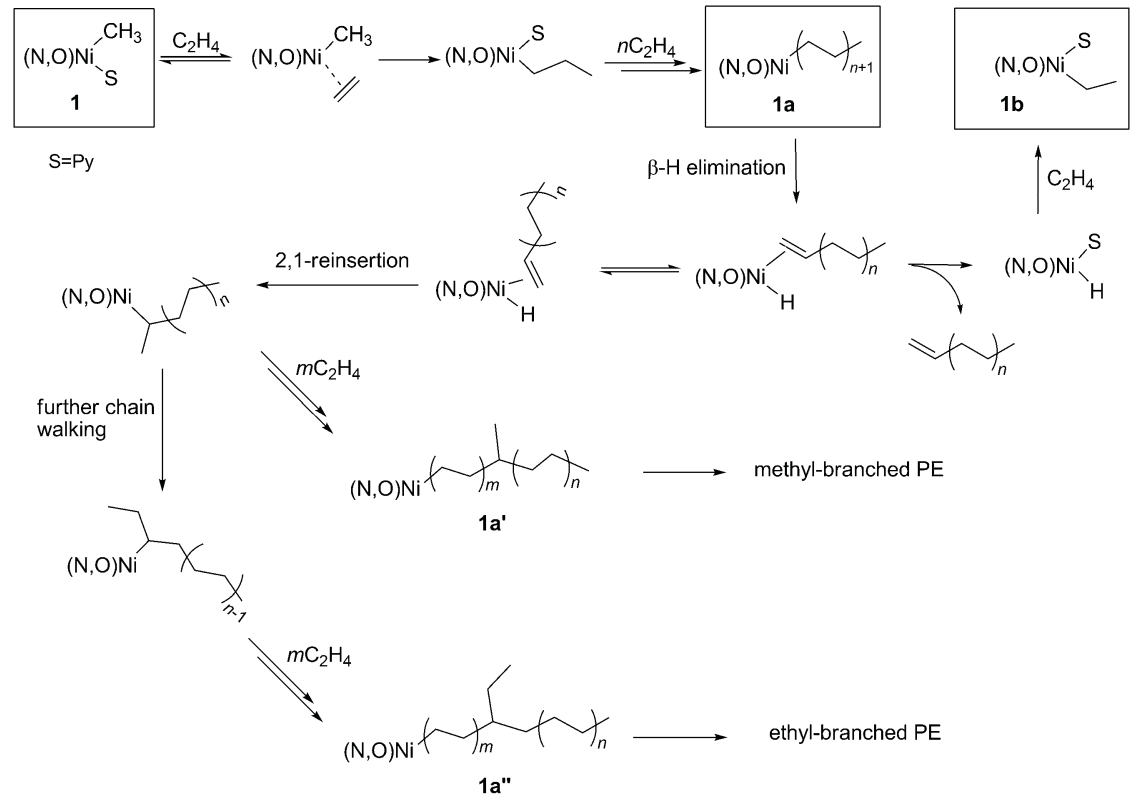

Scheme 2. Proposed pathways for the formation of nickel intermediates $\mathbf{1 a}$ and $\mathbf{1 b}$ and of branched polyethylenes. Compounds detected by NMR spectroscopic analysis are boxed.

and $\mathbf{2} \mathbf{a}$, and their absence in $\mathbf{3 a}$, however, the nature of their influence is not yet entirely clear. ${ }^{[21, \mathrm{p}, \mathrm{s}]}$

Catalyst deactivation: In the absence of ethylene, complexes 1-3 are stable in toluene solution at $+60^{\circ} \mathrm{C}$. In the course of ethylene polymerization at $+60^{\circ} \mathrm{C}$, however, these catalysts gradually decomposed (particularly when all injected ethylene was consumed), which led to a decrease in the ${ }^{1} \mathrm{H}$ NMR peaks of the diamagnetic $\mathrm{Ni}-\mathrm{Me}, \mathrm{Ni}-$ polymeryl, and $\mathrm{Ni}-\mathrm{Et}$ complexes. At the same time, a new species exhibiting highly paramagnetically shifted ${ }^{1} \mathrm{H}$ NMR peaks appeared. The ${ }^{1} \mathrm{H}$ NMR spectrum of a new species $\mathbf{1 c}$ in the catalyst system $\mathbf{1} /{ }^{13} \mathrm{C}_{2} \mathrm{H}_{4}$ is shown in Figure $3 \mathrm{~A}$. The latter exhibits a set of relatively sharp paramagnetically shifted peaks; most of them having integral intensities of $2 \mathrm{H}$, except the resonance at $\delta=16.4 \mathrm{ppm}$, which has an integral intensity of $1 \mathrm{H}$ (see Experimental Section). The shifts and line widths are characteristic of a high-spin nickel(II) complexe ${ }^{[8]}$ (apparently, nonplanar, ${ }^{[8 \mathrm{~d}]}$ in contrast to diamagnetic square-planar complexes $\mathbf{1}, \mathbf{1 b}$, and $\mathbf{1 c}$ ).

The temperature dependence of paramagnetic shifts obeyed the conventional Curie law ${ }^{[9 a]}$ (see Figure S9 and S10 in the Supporting Information), thus confirming the absence of antiferromagnetic interactions in the presumably mononuclear species 1c. The picture shown in Figure $1 \mathrm{~A}$ did not change when ${ }^{12} \mathrm{C}_{2} \mathrm{H}_{4}$ or ${ }^{12} \mathrm{C}_{2} \mathrm{D}_{4}$ was used instead of ${ }^{13} \mathrm{C}_{2} \mathrm{H}_{4}$, thus indicating that ethylene was not incorporated into the structure of $\mathbf{1 c}$

Reliable identification of the catalyst degradation product 1c is crucial because it can assist in unraveling the major deactivation pathways of salicylaldiminato nickel(II) catalysts. Fortunately, it was found that 1c was poorly soluble in nonpolar hydrocarbons, which allowed its isolation in crystalline form by layering its toluene solution with pentane (see the Experimental Section). X-ray analysis indicated that the crystals had a mononuclear bis-ligated structure $\left[(\mathrm{N}, \mathrm{O})_{2} \mathrm{Ni}\right]$. The quality of crystals of $\mathbf{1 c}$ obtained from the reaction mixture was insufficient for publication; for the latter purpose, the bis-ligated complex $\left(\mathbf{1} \mathbf{c}^{\prime}\right)$ was prepared independently by reaction of deprotonated ligand with anhydrous $\mathrm{NiCl}_{2}$ (see the Experimental Section) and was characterized by X-ray crystallography (Figure 4). NMR spectroscopic analysis indicated that 1c and 1 $\mathbf{c}^{\prime}$ had identical ${ }^{1} \mathrm{H}$ NMR spectra under similar conditions; furthermore, all their resonances were located within the diamagnetic region (see the Supporting Information, Figure S8). The origin of this behavior became clear when $\left[\mathrm{D}_{5}\right]$ pyridine was added to samples of $\mathbf{1 c}$ (Figure $3 \mathrm{~B}$ ) or $\mathbf{1} \mathbf{c}^{\prime}$ (Figure $3 \mathrm{C}$ ). In effect, formation of paramagnetic species was detected (Figure $3 \mathrm{~B}$ and $\mathrm{C}$ ). Intriguingly, the spectra presented in Figure $3 \mathrm{~B}$ and $\mathrm{C}$, as compared with that in Figure $3 \mathrm{~A}$, lack three ${ }^{1} \mathrm{H}$ peaks (due to $\left[\mathrm{D}_{5}\right]$ pyridine). This is indicative of the presence of one pyridine molecule in the structure of 1c.Py (in Figure $3 \mathrm{~A}$, pyridine peaks are marked as $\mathrm{Py}$ ). Additional $\left[\mathrm{D}_{5}\right]$ pyridine caused formation of another paramagnetic species (presumably 1c.2 Py, see Figure $3 \mathrm{C}$ ), which, under high pyridine/Ni ratios (ca. 100:1), became the major species in solution.

Taking the above observations together, our idea of the major deactivation pathway of catalyst $\mathbf{1}$ is the following (Scheme 3 and Scheme S1 of the Supporting Information). Apparently, under our experimental conditions, the deactivation is kinetically limited by the formation of the elusive $[(\mathrm{N}, \mathrm{O}) \mathrm{Ni}(\mathrm{H})]$ hydride species from the relatively stable $[(\mathrm{N}, \mathrm{O}) \mathrm{Ni}(\mathrm{Et})(\mathrm{Py})]$, followed by reductive elimination of the chelating ligand $(\mathrm{N}, \mathrm{O}) \mathrm{H}$. The resulting $(\mathrm{N}, \mathrm{O}) \mathrm{H}$ ligand can accumulate in solution and further react with the abundant $[(\mathrm{N}, \mathrm{O}) \mathrm{Ni}(\mathrm{Et})(\mathrm{Py})]$, releasing ethane and bis-ligated $\left[(\mathrm{N}, \mathrm{O})_{2} \mathrm{Ni}\right] \mathbf{1 c}^{[10 \mathrm{a}]}$ Similar deactivation pathways involving the reductive elimination of the chelating ligand were previously considered for nickel and palladium based catalyst systems. ${ }^{[3 \mathrm{~h}, \mathrm{j}, 1,4 \mathrm{j}]}$ We note that no precipitation of nickel black was observed. ${ }^{[10 b]}$

Variable temperature experiments revealed an abnormal temperature dependence of the paramagnetic line widths ${ }^{\left[{ }^{[b]}\right.}$ of ${ }^{1} \mathrm{H}$ NMR resonances of 1c.Py; unexpectedly, above $249 \mathrm{~K}$, the line widths increased with increasing temperature. Close inspection revealed that such behavior is caused by the dissociation of a coordinated pyridine molecule 

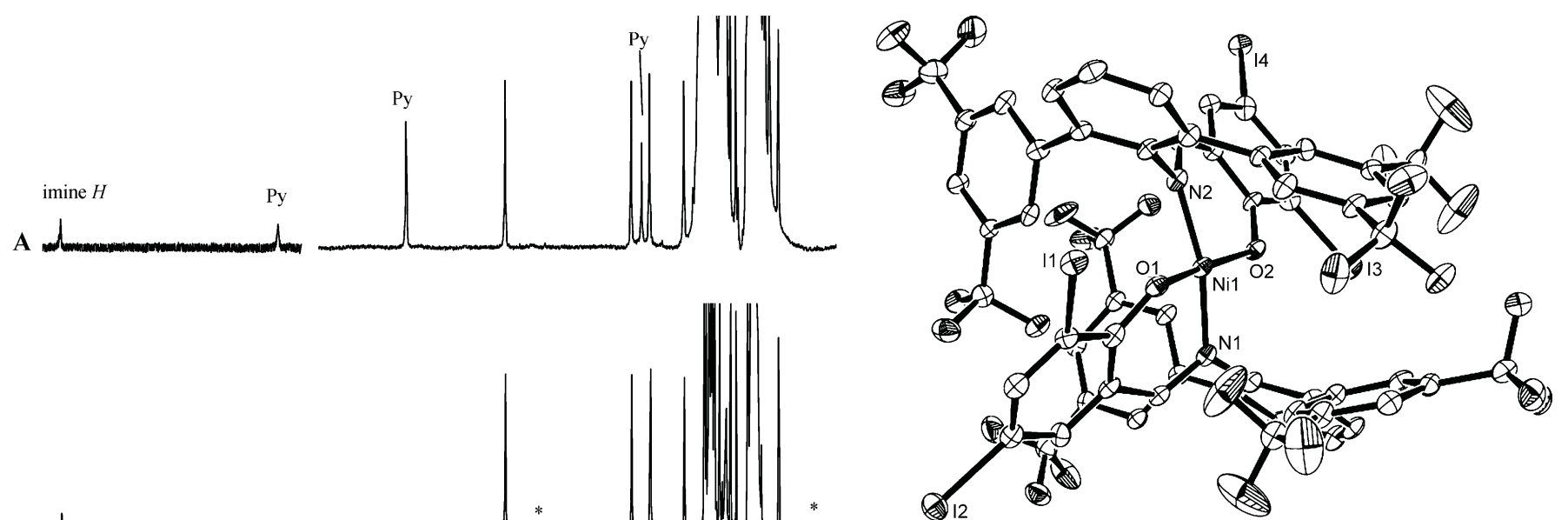

B
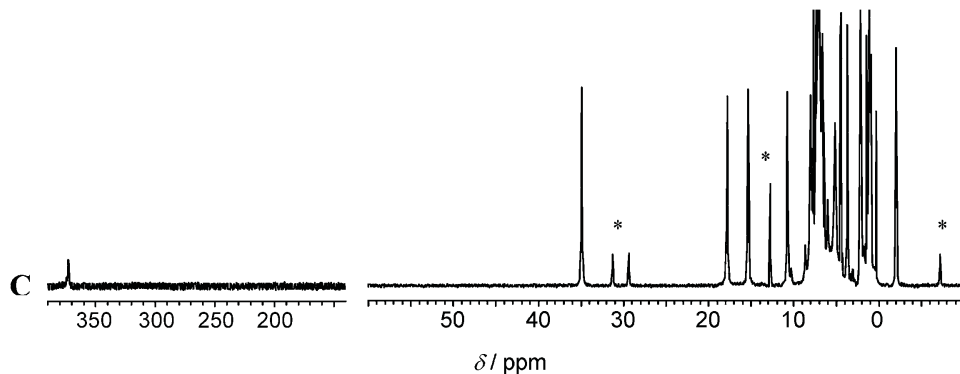

Figure 4 . Molecular structure of complex $\mathbf{1} \mathbf{c}^{\prime}$ with $25 \%$ probability ellipsoids.

ymers formed in the corresponding NMR samples after storing at $+60^{\circ} \mathrm{C}$ for at least $2 \mathrm{~h}$ and then 2 days at room temperature were isolated (Experimental section) and characterized by NMR spectroscopic analysis. Extensive chainwalking was evidenced by the presence of methyl and ethyl branches (Table 2). Signals from longer branches were

Figure $3 .{ }^{1} \mathrm{H}$ NMR spectra $\left(\left[\mathrm{D}_{8}\right]\right.$ toluene, $\left.0{ }^{\circ} \mathrm{C}\right)$. A) A $0.012 \mathrm{M}$ solution of catalyst 1 after the injection of 30 equiv of ${ }^{13} \mathrm{C}_{2} \mathrm{H}_{4}$ and storing for $82 \mathrm{~min}$ at $+60{ }^{\circ} \mathrm{C}$. B $)^{1} \mathrm{H}$ NMR spectrum of crystals of $\mathbf{1} \mathbf{c}+\left[\mathrm{D}_{5}\right]$ pyridine $(\mathrm{Py} / \mathrm{Ni}$ ca. 1.5:1). C) ${ }^{1} \mathrm{H}$ NMR spectrum of independently prepared bis-ligated complex $\mathbf{1} \mathbf{c}^{\prime}\left(\left[(\mathrm{N}, \mathrm{O})_{2} \mathrm{Ni}\right]\right)+\left[\mathrm{D}_{5}\right]$ pyridine $(\mathrm{Py} / \mathrm{Ni}$ of $5: 1)$. Peaks of coordinated pyridine are marked as Py. Small peaks of another paramagnetic complex (1c.2Py) are marked with asterisks.

(Scheme 3, bottom), with activation energy for its dissociation of $(12.3 \pm 0.5) \mathrm{kcal} \mathrm{mol}^{-1}, \quad \Delta H^{\neq}{ }_{298}=(11.7 \pm 0.5) \mathrm{kcal}$ $\mathrm{mol}^{-1}, \Delta S^{\neq}{ }_{298}=(-7 \pm 1) \mathrm{cal} \mathrm{K}^{-1} \mathrm{~mol}^{-1}$ (see the Supporting Information, Figure S9-S11). On the other hand, upon the addition of pentane, the pyridine ligand is lost completely to form crystals of nearly planar diamagnetic $\left[(\mathrm{N}, \mathrm{O})_{2} \mathrm{Ni}\right]$ complex 1c (see above).

Chain termination-inspection of the polymer end groups: To evaluate the structure of polymeric products and ascertain the major processes responsible for chain termination in catalyst systems based on complexes $\mathbf{1}-\mathbf{3},{ }^{13} \mathrm{C}$-labeled pol-
Table 2. Properties of ${ }^{13} \mathrm{C}-\mathrm{PE}$ isolated from the catalyst systems studied. ${ }^{\text {[a] }}$

\begin{tabular}{lrlrlll}
\hline Sample & $M_{\mathrm{n}}$ & $\begin{array}{l}\text { Branches/ } \\
\text { 1000C } \\
\text { Methyl }\end{array}$ & Ethyl & $\begin{array}{l}\text { Double bonds, per molecule } \\
\text { Terminal } \\
\text { vinyl }\end{array}$ & $\begin{array}{l}\text { Terminal vinylene } \\
\text { (cis/trans) }\end{array}$ & $\begin{array}{l}\text { Internal } \\
\text { vinylene }\end{array}$ \\
\hline $\mathbf{1} /{ }^{13} \mathrm{C}_{2} \mathrm{H}_{4}$ & 633 & 22 & $<2$ & 0.14 & $0.53(46: 54)$ & 0.33 \\
$\mathbf{2} /{ }^{13} \mathrm{C}_{2} \mathrm{H}_{4}$ & 1008 & 21 & 3 & - & $0.29(57: 43)$ & 0.61 \\
$\mathbf{3} /{ }^{13} \mathrm{C}_{2} \mathrm{H}_{4}$ & 476 & 67 & 23 & - & $0.35(52: 48)$ & 0.65 \\
\hline
\end{tabular}

[a] According to ${ }^{13} \mathrm{C}$ and ${ }^{1} \mathrm{H}$ NMR data.

below the NMR detection limit. The resulting polymers were found to have one olefinic group per polymer molecule. Interestingly, vinylene (terminal and internal, cis+trans, see Figure 5) groups predominated over terminal vinyl groups. Apparently, fast chain walking facilitates the formation of more thermodynamically favored internal double bonds rather than terminal double bonds (Scheme 4). None of the three catalysts studied exhibited cis- or trans-selectivity for double bond formation. As could be expected, ${ }^{[21]}$ catalyst 3 yielded the shortest and the most highly branched polymeric product, whereas polyethylenes formed in samples containing $\mathbf{1}$ and $\mathbf{2}$ featured lower amounts of branches per 1000 C (Table 2). A more detailed NMR characterization of polymers formed can be found
Scheme 3. Hypothetical pathways for catalyst deactivation in the system $1 / \mathrm{C}_{2} \mathrm{H}_{4}$ and dynamic equilibrium involving 1 c. $\mathrm{S}=$ pyridine, solvent molecule, or vacancy. 

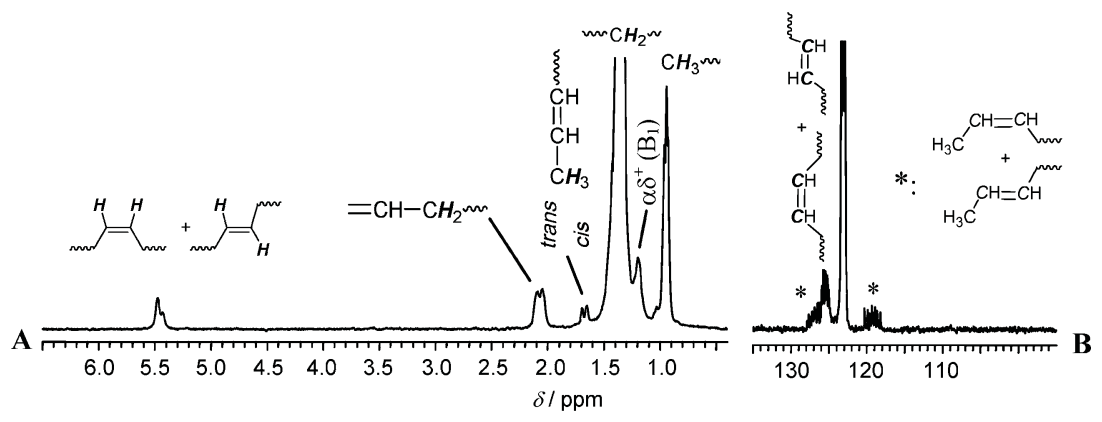

Figure 5. A) ${ }^{1} \mathrm{H}\left\{{ }^{13} \mathrm{C}\right\}$ and B) ${ }^{13} \mathrm{C}\left\{{ }^{1} \mathrm{H}\right\}$ inverse-gated NMR spectra of ${ }^{13} \mathrm{C}$-polyethylene $\left(\mathrm{CDCl}_{3} / \mathrm{C}_{6} \mathrm{D}_{6}, 60^{\circ} \mathrm{C}\right)$ isolated from the sample containing species $\mathbf{2 b}$ $\mathbf{1}, \mathbf{2}, \mathbf{1 b}$, and $\mathbf{2} \mathbf{b}$, and of $\mathbf{1 a}$ and $\mathbf{2 a}$ at various ethylene consumptions were estimated (Table 3).

It appears that even at this rather approximate level (the technique does not take into account the presence of branches in the polymeryl chain, or conformation of the latter), $\mathrm{PFG}$ NMR provides a reasonably plausible direct size-estimate of the chain-propagating inter-

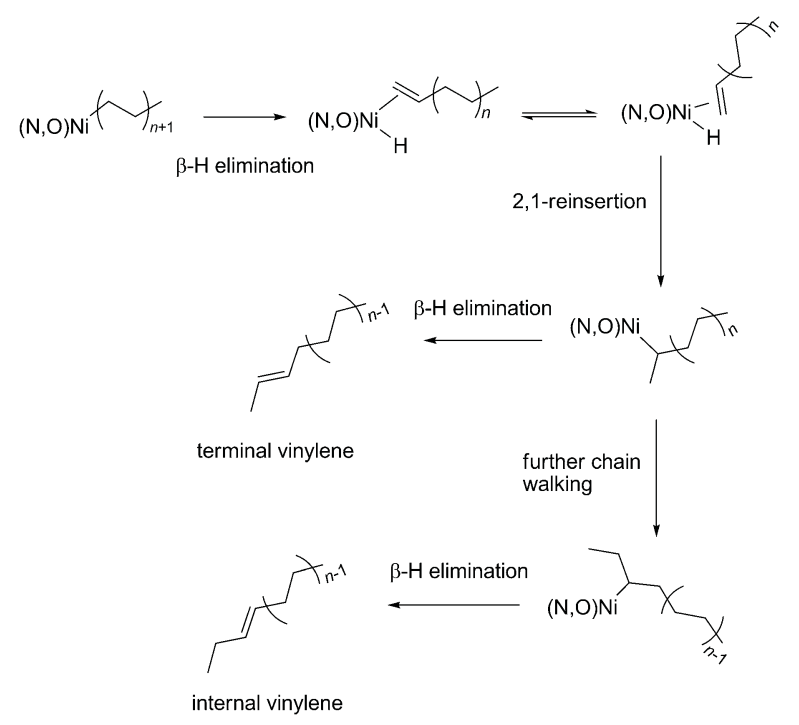

Scheme 4. Proposed scheme for chain termination. Branches are not shown for simplicity.

in the Supporting information (Figure S12-S14). For resonance assignments, we used conventional Randall-Carman nomenclature ${ }^{[11 \mathrm{a}]}$ and consulted some relevant literature. ${ }^{[11]}$

Evaluation of the size of Ni-polymeryl species by pulsedfield-gradient (PFG) NMR spectroscopy: Evaluation of the size of active species operating in coordination polymerization of olefins is a challenging task; this knowledge is of particular value for a detailed understanding of their nature and solution behavior. In recent years, ${ }^{1} \mathrm{H}$ PFG NMR ${ }^{[12]}$ has been successfully applied for the determination of translational diffusion coefficients and size estimates of cationic precursors of propagating species in various single-site olefin polymerization catalysts. ${ }^{[13]}$ In this work, we report the first PFG NMR based determination of the size of chain-propagating species $1 \mathbf{a}$ and $\mathbf{2 a}$ formed upon the interaction of catalysts $\mathbf{1}$ and $\mathbf{2}$ with ethylene in $\left[\mathrm{D}_{8}\right]$ toluene. Using the dstegp3s1d pulse sequence, taking advantage of convection compensation, ${ }^{[12 c]}$ the diffusion-average radii of
Table 3. Radii, volumes, and estimated lengths of various nickel species $\left(\left[\mathrm{D}_{8}\right]\right.$ toluene, $\left.-20^{\circ} \mathrm{C}\right) \cdot{ }^{[\mathrm{a}]}$

\begin{tabular}{|c|c|c|c|c|}
\hline Entry & Species & $\begin{array}{l}t \\
{[\mathrm{~min}]^{[\mathrm{b}]}}\end{array}$ & $\begin{array}{l}r_{\mathrm{H}} \\
{[\AA]^{[\mathrm{cc}]}}\end{array}$ & $\begin{array}{l}\text { Polymeryl, } \\
n-\left(\mathrm{C}_{2} \mathrm{H}_{4}\right)^{[\mathrm{d}]}\end{array}$ \\
\hline 1 & $\mathbf{1}\left[(\mathrm{N}, \mathrm{O}) \mathrm{Ni}\left(\mathrm{CH}_{3}\right)(\mathrm{Py})\right]^{[\mathrm{e}]}$ & - & 5.96 & - \\
\hline 2 & $\mathbf{1} \mathbf{a}[(\mathrm{N}, \mathrm{O}) \mathrm{Ni}(\text { polymeryl })]^{[\mathrm{f}]}$ & 2 & 6.80 & 11 \\
\hline 3 & $\mathbf{1} \mathbf{a}[(\mathrm{N}, \mathrm{O}) \mathrm{Ni}(\text { polymeryl })]^{[f]}$ & 5 & 7.07 & $14-15$ \\
\hline 4 & $\mathbf{1} \mathbf{a}[(\mathrm{N}, \mathrm{O}) \mathrm{Ni}(\text { polymeryl })]^{[f]}$ & 10 & 7.00 & 14 \\
\hline 5 & $\mathbf{1} \mathbf{a}[(\mathrm{N}, \mathrm{O}) \mathrm{Ni}(\text { polymeryl })]^{[f]}$ & 20 & 6.73 & $10-11$ \\
\hline 6 & $\mathbf{1} \mathbf{a}[(\mathrm{N}, \mathrm{O}) \mathrm{Ni}(\text { polymeryl })]^{[f]}$ & 32 & 6.37 & $6-7$ \\
\hline 7 & $\mathbf{1 b}[(\mathrm{N}, \mathrm{O}) \mathrm{Ni}(\mathrm{Et})(\mathrm{Py})]^{[\mathrm{e}]}$ & 60 & 5.96 & - \\
\hline 8 & $2\left[(\mathrm{~N}, \mathrm{O}) \mathrm{Ni}\left(\mathrm{CH}_{3}\right)(\mathrm{Py})\right]^{[\mathrm{ee}]}$ & - & 6.34 & - \\
\hline 9 & $\mathbf{2 a}[(\mathrm{N}, \mathrm{O}) \mathrm{Ni}(\text { polymeryl })]^{[\mathrm{g}]}$ & 2 & 7.40 & 16 \\
\hline 10 & 2a $[(\mathrm{N}, \mathrm{O}) \mathrm{Ni}(\text { polymeryl })]^{[\mathrm{g}]}$ & 5 & 7.48 & 17 \\
\hline 11 & 2a $[(\mathrm{N}, \mathrm{O}) \mathrm{Ni}(\text { polymeryl })]^{[\mathrm{g}]}$ & 20 & 7.56 & 18 \\
\hline 12 & 2a $[(\mathrm{N}, \mathrm{O}) \mathrm{Ni}(\text { polymeryl })]^{[\mathrm{g}]}$ & 40 & 7.33 & 15 \\
\hline 13 & $\mathbf{2 b}[(\mathrm{N}, \mathrm{O}) \mathrm{Ni}(\mathrm{Et})(\mathrm{Py})]^{[\mathrm{e}]}$ & 60 & 6.34 & - \\
\hline
\end{tabular}

[a] For measurement details see the Supporting Information. [b] Time of interaction at $+60^{\circ} \mathrm{C}$. [c] Hydrodynamic radius. [d] For the evaluation of the polymeryl chain lengths see the Supporting Information. [e] at $303 \mathrm{~K}$. [f] $\mathrm{C}_{2} \mathrm{H}_{4} / \mathbf{1}=30 .[\mathrm{g}] \mathrm{C}_{2} \mathrm{H}_{4} / \mathbf{2}=30$.

mediates. The estimated average hydrodynamic radii of the chain-propagating intermediates demonstrated a nonmonotonic behavior; they increased in intensity at the early stages of the interaction (2-5 min for catalyst 1 and 2-20 min for catalyst 2), and decreased at high ethylene consumption, thus reflecting the nonstationary character of the polymerization process in the NMR tube in which no continuous ethylene inflow could be arranged. The highest observed radii corresponded to polymeryl chain lengths of 15-18 $\mathrm{C}_{2} \mathrm{H}_{4}$ units.

Upon prolonged storage at $+60^{\circ} \mathrm{C}(40-60 \mathrm{~min})$, the amount of $[(\mathrm{N}, \mathrm{O}) \mathrm{Ni}$ (polymeryl)] intermediate decreased, whereas the concentrations of relatively stable $(\mathrm{N}, \mathrm{O}) \mathrm{Ni}-\mathrm{Et}$ intermediates increased and became sufficient for the PFG measurements. Significantly, the estimated radii of Ni-Et intermediates $\mathbf{1 b}$ and $\mathbf{2 b}$ were very close to those of the parent catalysts $\mathbf{1}$ and $\mathbf{2}$, respectively (Table 3, entries 1, 7 and 8,13 ), in line with our suggestion that a pyridine molecule is likely to remain in the structures of $\mathbf{1 b}$ and $\mathbf{2 b}$ $\left[(\mathrm{N}, \mathrm{O}) \mathrm{Ni}\left(\mathrm{C}_{2} \mathrm{H}_{5}\right)(\mathrm{Py})\right]$ (see above). More data are reported in the Supporting Information. 


\section{Conclusion}

The polymer chain growth on salicylaldiminato nickel(II) catalysts $\left[(\mathrm{N}, \mathrm{O}) \mathrm{Ni}\left(\mathrm{CH}_{3}\right)(\mathrm{Py})\right]($ where $(\mathrm{N}, \mathrm{O})=$ salicylaldimine ligand) has been observed directly by NMR spectroscopy. Storing solutions containing $\left[{ }^{13} \mathrm{C}_{2}\right]$ ethylene and catalysts $\mathbf{1}$ or 2 (ethylene $/ \mathrm{Ni}=10: 30$ ) at $+60^{\circ} \mathrm{C}$ for controlled (short) periods of time results in the generation of $[(\mathrm{N}, \mathrm{O}) \mathrm{Ni}$ (polymeryl)] propagating species $1 \mathbf{a}$ or $2 \mathbf{a}$. At $-20^{\circ} \mathrm{C}$, the latter are stable and can be characterized by ${ }^{1} \mathrm{H}$ and ${ }^{13} \mathrm{C}$ NMR spectroscopy. At $+60^{\circ} \mathrm{C}$, the amounts of $[(\mathrm{N}, \mathrm{O}) \mathrm{Ni}$ (polymeryl) $]$ intermediates $\mathbf{1 a}$ and $\mathbf{2} \mathbf{a}$ decrease at high ethylene consumptions, yielding free polymer molecules and [(N,O)Ni$\left.\left(\mathrm{C}_{2} \mathrm{H}_{5}\right)(\mathrm{Py})\right]$ species. The latter are stable for hours at $+60^{\circ} \mathrm{C}$. For catalyst 3 (without $\mathrm{CF}_{3}$ substituents), Ni-polymeryl intermediates are not detected under identical experimental conditions \{only $\left[(\mathrm{N}, \mathrm{O}) \mathrm{Ni}\left(\mathrm{C}_{2} \mathrm{H}_{5}\right)(\mathrm{Py})\right](\mathbf{3 b})$, which is in accordance with the higher propensity of $\mathbf{3}$ to chain termination through $\beta$-hydride elimination. NMR spectroscopic analysis of polyethylenes formed indicates the presence of one olefinic group (predominately cis- and trans-vinylene groups rather than terminal vinyl groups) per PE molecule. The behavior of the Ni catalysts under these conditions resembles their behavior under typical preparative polymerization conditions in a pressure reactor, in that $\mathbf{3}$ affords shorter and more densely branched PE than $\mathbf{1}$ and $\mathbf{2}$.

Our data agree with earlier predictions that the major catalyst deactivation pathway, at least at high ethylene conversions, may be associated with reductive elimination of the free salicylaldiminate ligand $(\mathrm{N}, \mathrm{O}) \mathrm{H}$ from the elusive nickel hydride intermediate $[(\mathrm{N}, \mathrm{O}) \mathrm{Ni}(\mathrm{H})(\mathrm{S})](\mathrm{S}=$ solvent, pyridine, or vacancy). The free ligand is likely to further react with the abundant nickel compound $[(\mathrm{N}, \mathrm{O}) \mathrm{Ni}(\mathrm{Et})(\mathrm{Py})]$ to yield the ultimate catalyst degradation product, a paramagnetic $\left[(\mathrm{N}, \mathrm{O})_{2} \mathrm{Ni}(\mathrm{Py})\right]$ complex, in which the pyridine ligand is labile (with activation energy for its dissociation of $12.3 \mathrm{kcal}$ $\mathrm{mol}^{-1}$ ). Upon addition of a nonpolar solvent, the pyridine ligand is lost completely to yield the nearly square-planar $\left[(\mathrm{N}, \mathrm{O})_{2} \mathrm{Ni}\right]$ diamagnetic complex in a crystalline form.

Using PFG ${ }^{1} \mathrm{H}$ NMR measurements, the hydrodynamic radii of $[(\mathrm{N}, \mathrm{O}) \mathrm{Ni}($ polymeryl $)]$ chain propagating intermediates $\mathbf{1 a}$ and $\mathbf{2 a}$ and average polymeryl chain lengths (polymeryl $\left.=\left(\mathrm{CH}_{2}\right)_{n} \mathrm{H}, n=6-18\right)$ were estimated at various stages of catalysts interaction with $\mathrm{C}_{2} \mathrm{H}_{4}$. In the course of the reaction, the average radii initially increased, then decreased at high ethylene consumption. Although of approximate nature, owing to the neglect of chain branches and conformational effects, these data still provide the first plausible NMR-based size-estimate of chain-propagating intermediates at the early stages of ethylene polymerization in a practical post-metallocene catalyst system.

\section{Experimental Section}

General remarks: Complexes 1-3, were prepared as described. ${ }^{[2]]}$ $\left[{ }^{13} \mathrm{C}_{2}\right]$ Ethene $\left(99 \%{ }^{13} \mathrm{C}\right)$ was purchased from Aldrich, $\left[\mathrm{D}_{8}\right]$ toluene was dried over molecular sieves ( $4 \AA$ ) and degassed prior to use. All operations were carried out under dry argon $(99.999 \%)$ by using standard Schlenk techniques. Solids were stored in a glove box.

${ }^{1} \mathrm{H}$ and ${ }^{13} \mathrm{C}$ NMR spectra were recorded in standard $5 \mathrm{~mm}$ NMR tubes with a Bruker Avance III $600 \mathrm{MHz}$ spectrometer by using a $5 \mathrm{~mm}$ TXI probe, at 600.24 and $150.94 \mathrm{MHz}$, respectively. Typical operating conditions for ${ }^{13} \mathrm{C}$ NMR measurements: spectral width $40 \mathrm{kHz}$; spectrum accumulation frequency $0.1-0.05 \mathrm{~Hz} ; 500-5000$ transients, $90^{\circ}$ pulse at $13.0 \mu \mathrm{s}$. Operating conditions for ${ }^{1} \mathrm{H}$ NMR measurements: spectral width $15 \mathrm{kHz}$; spectrum accumulation frequency $0.2-0.25 \mathrm{~Hz}$; number of transients 32 $64,90^{\circ}$ pulse at $8.8 \mu \mathrm{s} .{ }^{1} \mathrm{H}$ and ${ }^{13} \mathrm{C}$ chemical shifts are referenced internally to the $\mathrm{CHD}_{2}$-group of toluene, $\delta=2.12 \mathrm{ppm}\left({ }^{1} \mathrm{H}\right)$ and $\mathrm{CD}_{3}$-group of toluene, $\delta=20.40 \mathrm{ppm}\left({ }^{13} \mathrm{C}\right)$, respectively. Sample temperature measurements uncertainty and temperature reproducibility did not exceed $\pm 1{ }^{\circ} \mathrm{C}$. Sample preparation: An appropriate amount of nickel complex (typically, $6 \mu \mathrm{mol})$ was placed in a $5 \mathrm{~mm}$ NMR tube in a glove box, $\left[\mathrm{D}_{8}\right]$ toluene $(0.6 \mathrm{~mL})$ was added, and the tube was capped with a rubber septum. The tube was taken out of the glovebox, cooled in acetone/liquid $\mathrm{N}_{2}$ mixture, and ethylene (or $\left[{ }^{13} \mathrm{C}_{2}\right]$ ethylene) was injected by using a gas-tight syringe. Polymers for ${ }^{13} \mathrm{C}$ analysis were prepared by storing the samples in $\left[D_{8}\right]$ toluene solutions of $1 /{ }^{13} \mathrm{C}_{2} \mathrm{H}_{4}, 2 /{ }^{13} \mathrm{C}_{2} \mathrm{H}_{4}$, or $3 /{ }^{13} \mathrm{C}_{2} \mathrm{H}_{4}$ (ethylene/ $\mathrm{Ni}=$ $30: 1$ ) for $2 \mathrm{~h}$ at $+60^{\circ} \mathrm{C}$, and precipitated by opening the samples to air and diluting them with water/methanol solutions. The supernatant was removed and the solids were washed several times with methanol and dried in a vacuum.

Diffusion measurements were performed with a Bruker Avance III $600 \mathrm{MHz}$ NMR spectrometer, equipped with a TXI probe with Z-gradient. Sample solutions were prepared by dissolving weighed amounts of catalyst $\mathbf{1}$ or $\mathbf{2}$ in a $5 \mathrm{~mm}$ NMR tube in $\left[\mathrm{D}_{8}\right]$ toluene and closing the tube with a septum stopper, followed by the injection of ethylene by using a gas-tight microsyringe upon cooling the sample outside the glovebox. The PFG NMR measurements were performed at 253 and $303 \mathrm{~K}$ using the pulse sequence dstegp3s1d, ${ }^{[12 c]}$ 10-14 different gradient strengths (from 0.5 to $50 \mathrm{G} / \mathrm{cm}$ ), gradient pulse durations $1.6-4.0 \mathrm{~ms}$, diffusion time of $100 \mathrm{~ms}$, longitudinal eddy current delay of $5 \mathrm{~ms}$, relaxation delays of $60 \mathrm{~s}, 8$ or 16 transients, $64 \mathrm{~K}$ points. For further details see the Supporting Information.

Formation of $1 \mathrm{c} \cdot \mathrm{Py}$ in the course of polymerization of ethylene by catalyst 1: To a solution of catalyst $1\left(0.012 \mathrm{M}\right.$ in $\left[\mathrm{D}_{8}\right]$ toluene, $\left.0.6 \mathrm{~mL}\right)$ in an NMR tube, ${ }^{13} \mathrm{C}_{2} \mathrm{H}_{4}$ (30 equiv) was injected at reduced temperature (below $-20^{\circ} \mathrm{C}$ ). The sample was stored in a thermostated bath at $+60^{\circ} \mathrm{C}$ for $82 \mathrm{~min}$ (when $\left[{ }^{13} \mathrm{C}_{2}\right]$ ethylene was consumed). ${ }^{1} \mathrm{H}$ NMR $(600.24 \mathrm{MHz}$, $\left[\mathrm{D}_{8}\right]$ toluene, $0{ }^{\circ} \mathrm{C}$, TMS): $\delta$ (data for paramagnetic species $\left.\mathbf{1} \cdot \mathrm{Py}\right)=372.8$ $(2 \mathrm{H}$; imine $H),{ }^{[8 a]} 162.5(2 \mathrm{H} ; \mathrm{Py}), 48.2(2 \mathrm{H} ; \mathrm{Py}), 34.9(2 \mathrm{H}), 17.8(2 \mathrm{H})$, 16.4 (1 H; Py), $15.3(2 \mathrm{H}), 10.7(2 \mathrm{H}), 4.4(2 \mathrm{H}), 3.7(2 \mathrm{H}),-2.1 \mathrm{ppm}(2 \mathrm{H})$. Some signals were not found due to overlapping with peaks of PE and with those of residual $\mathbf{1}$ and $\mathbf{1 b}$. The sample was stored at RT overnight, then the precipitate of polyethylene was filtered off under inert atmosphere. The solute was placed in a $5 \mathrm{~mm}$ NMR tube, and pentane (ca. $1 \mathrm{~mL}$ ) was layered upon. Dark-brown crystals formed in a few days, which were separated and dried in a glovebox atmosphere. ${ }^{1} \mathrm{H}$ NMR $\left(600.24 \mathrm{MHz},\left[\mathrm{D}_{8}\right]\right.$ toluene, $0{ }^{\circ} \mathrm{C}$, TMS): $\delta($ data for $\mathbf{1 c})=7.98\left(\mathrm{~s}, 4 \mathrm{H} ; \mathrm{H}_{\mathrm{b}}\right)$, $7.73\left(\mathrm{~d},{ }^{3} J(\mathrm{H}, \mathrm{H})=2 \mathrm{~Hz}, 2 \mathrm{H} ; \mathrm{H}_{\mathrm{e}}\right), 7.35\left(\mathrm{~s}, 8 \mathrm{H} ; \mathrm{H}_{\mathrm{a}}\right), 6.86\left(\mathrm{t},{ }^{3} J(\mathrm{H}, \mathrm{H})=\right.$ $\left.7.8 \mathrm{~Hz}, 2 \mathrm{H} ; \mathrm{H}_{\mathrm{c}}\right), 6.62\left(\mathrm{~d},{ }^{3} J(\mathrm{H}, \mathrm{H})=7.8 \mathrm{~Hz}, 4 \mathrm{H} ; \mathrm{H}_{\mathrm{d}}\right), 6.59\left(\mathrm{~d},{ }^{3} J(\mathrm{H}, \mathrm{H})=\right.$ $\left.2 \mathrm{~Hz}, 2 \mathrm{H} ; \mathrm{H}_{\mathrm{f}}\right), 5.90\left(\mathrm{~s}, 2 \mathrm{H} ; \mathrm{H}_{\mathrm{g}}\right)$.

Independent synthesis of $1 \mathbf{c}^{\prime}$ : Bis-ligated complex $\mathbf{1 c}^{\prime}$ was prepared as follows. (N,O)H (100.6 mg, $0.12 \mathrm{mmol}, 2$ equiv), $\mathrm{NaH}(12 \mathrm{mg}, 0.50 \mathrm{mmol}$, 4 equiv), and anhydrous $\mathrm{NiCl}_{2}(7.6 \mathrm{mg}, 0.06 \mathrm{mmol}, 1$ equiv) were suspended in absolute THF $(6 \mathrm{~mL})$ and stirred for $72 \mathrm{~h}$ at RT. The solvent was removed in vacuo and the brown residue was suspended in anhydrous toluene $(2 \mathrm{~mL})$, filtered, and the filtrate was covered with anhydrous pentane $(5 \mathrm{~mL})$. Storage at $4{ }^{\circ} \mathrm{C}$ yielded brown crystals of $\mathbf{1 c}^{\prime}$ (69 mg, $0.04 \mathrm{mmol}, 67 \%)$ that were suitable for X-ray analysis. ${ }^{1} \mathrm{H}$ NMR $\left(600.24 \mathrm{MHz},\left[\mathrm{D}_{8}\right]\right.$ toluene, $-20^{\circ} \mathrm{C}$, TMS): $\delta\left(\right.$ for $\left.\mathbf{1} \mathbf{c}^{\prime}\right)=7.98\left(\mathrm{~s}, 4 \mathrm{H} ; \mathrm{H}_{\mathrm{b}}\right)$, $7.73\left(\mathrm{~d},{ }^{3} J(\mathrm{H}, \mathrm{H})=2 \mathrm{~Hz}, 2 \mathrm{H} ; \mathrm{H}_{\mathrm{e}}\right), 7.34\left(\mathrm{~s}, 8 \mathrm{H} ; \mathrm{H}_{\mathrm{a}}\right), 6.83\left(\mathrm{t},{ }^{3} J(\mathrm{H}, \mathrm{H})=\right.$ $\left.7.8 \mathrm{~Hz}, 2 \mathrm{H} ; \mathrm{H}_{\mathrm{c}}\right), 6.57\left(\mathrm{~d},{ }^{3} J(\mathrm{H}, \mathrm{H})=2 \mathrm{~Hz}, 2 \mathrm{H} ; H_{\mathrm{f}}\right), 6.55\left(\mathrm{~d},{ }^{3} J(\mathrm{H}, \mathrm{H})=\right.$ $\left.7.8 \mathrm{~Hz}, 4 \mathrm{H} ; \mathrm{H}_{\mathrm{d}}\right), 5.80 \mathrm{ppm}\left(\mathrm{s}, 2 \mathrm{H} ; \mathrm{H}_{\mathrm{g}}\right)$. 


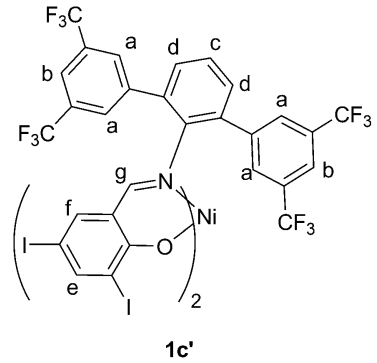

X-ray measurements: X-Ray diffraction analysis was performed at $100 \mathrm{~K}$ with a STOE IPDS-II diffractometer equipped with a graphite-monochromated radiation source $(\lambda=0.71073 \AA)$ and an image plate detection system. Crystals were mounted on a fine glass fiber with silicon grease. The selection, integration, and averaging procedure of the measured reflex intensities, the determination of the unit cell dimensions, and a least-squares fit of the $2 \theta$ values as well as data reduction are described in the Electronic Supporting Information. CCDC-910995 contains the supplementary crystallographic data for this paper. These data can be obtained free of charge from The Cambridge Crystallographic Data Centre via www.ccdc.cam.ac.uk/data_request/cif

\section{Acknowledgements}

The authors are grateful to Dr. Valentina Panchenko, Mrs. Anke Friemel, Dipl. Ing. (FH) Ulrich Haunz, Dipl. Chem. Philipp Wucher, and Prof. Hans-Herbert Brintzinger for their voluntary contribution to planning the experiments and discussing the results, as well as for their technical and organizational assistance. Financial support from the DFG and RFBR (grant Me 1388/9-1/10-03-91330) and from RFBR (grant 12-0391159) is gratefully acknowledged.

[1] a) L. K. Johnson, C. M. Killian, M. Brookhart, J. Am. Chem. Soc. 1995, 117, 6414-6415; b) C. M. Killian, D. J. Tempel, L. K. Johnson, M. Brookhart, J. Am. Chem. Soc. 1996, 118, 11664-11665; c) M. D. Leatherman, S. A. Svejda, L. K. Johnson, M. Brookhart, J. Am. Chem. Soc. 2003, 125, 3068-3081.

[2] a) C. Wang, S. Friedrich, T. R. Younkin, R. T. Li, R. H. Grubbs, D. A. Bansleben, M. W. Day, Organometallics 1998, 17, 3149-3151; b) L. K. Johnson, A. M. A. Bennett, S. D. Ittel, L. Wang, A. Parthasarathy, E. Hauptman, R. D. Simpson, J. Feldman, E. B. Coughlin (DuPont), WO98/30609, 1998; c) A. Tomov, R. Spitz, T. Saudemont, X. Drujon (Elf Atochem, S. A.), French Patent 98.12476, 1998; d) A. Held, F. M. Bauers, S. Mecking, Chem. Commun. 2000, 301302 ; e) D. P. Gates, S. A. Svejda, E. Onate, C. M. Killian, L. K. Johnson, P. S. White, M. Brookhart, Macromolecules 2000, 33, 23202334; f) M. D. Leatherman, M. Brookhart, Macromolecules 2001, 34 , 2748-2750; g) R. Soula, J. P. Broyer, M. F. Llauro, A. Tomov, R. Spitz, J. Claverie, X. Drujon, J. Malinge, T. Saudemont, Macromolecules 2001, 34, 2438-2442; h) V. C. Gibson, A. Tomov, A. J. P. White, D. J. Williams, Chem. Commun. 2001, 719-720; i) M. Zuideveld, P. Wehrmann, C. Röhr, S. Mecking, Angew. Chem. 2004, 116, 887-891; Angew. Chem. Int. Ed. 2004, 43, 869-873; j) L. Zhang, M. Brookhart, P. S. White, Organometallics 2006, 25, 1868-1874; k) P. Kuhn, D. Sémeril, C. Jeunesse, D. Matt, M. Neuburger, A. Mota, Chem. Eur. J. 2006, 12, 5210-5219; 1) I. Göttker-Schnetmann, P. Wehrmann, C. Röhr, S. Mecking, Organometallics 2007, 26, 23482362; m) S.-M. Yu, A. Berkefeld, I. Göttker-Schnetmann, G. Müller, S. Mecking, Macromolecules 2007, 40, 421-428; n) L. Lavanant, A.S. Rodriguez, E. Kirillov, J.-F. Carpentier, R. F. Jordan, Organometallics 2008, 27, 2107-2117; o) D. P. Song, W. P. Ye, Y. X. Wang, J. Y. Liu, Y. S. Li, Organometallics 2009, 28, 5697-5704; p) C. S. Popeney, A. L. Rheingold, Z. Guan, Organometallics 2009, 28, 4452-4463; q) D. P. Song, Y. X. Wang, H. L. Mu, B. X. Li, Y. S. Li, Organometallics 2011, 30, 925-934; r) M. P. Weberski, Jr., C. Chen, M. Delferro, T. J. Marks, Chem. Eur. J. 2012, 18, 10715-10732; s) M. P. Weberski, C. Chen, M. Delferro, C. Zuccaccia, A. Macchioni, T. J. Marks, Organometallics 2012, 31, 3773-3789.

[3] a) W. Keim, F. H. Kowaldt, R. Goddard, C. Krüger, Angew. Chem. 1978, 90, 493-493; Angew. Chem. Int. Ed. Engl. 1978, 17, 466-467; b) W. Keim, R. Appel, A. Storeck, C. Krüger, R. Goddard, Angew. Chem. 1981, 93, 91-92; Angew. Chem. Int. Ed. Engl. 1981, 20, 116 117; c) K. A. Ostoja Starzewski, J. Witte, Angew. Chem. 1985, 97, 610-612; Angew. Chem. Int. Ed. Engl. 1985, 24, 599-601; d) V. M. Möhring, G. Fink, Angew. Chem. 1985, 97, 982-984; Angew. Chem. Int. Ed. Engl. 1985, 24, 1001-1003; e) U. Klabunde, S. D. Ittel, J. Mol. Catal. 1987, 41, 123-134; f) T. R. Younkin, E. F. Connor, J. I Henderson, S. K. Friedrich, R. H. Grubbs, D. A. Bansleben, Science 2000, 287, 460-462; g) F. A. Hicks, M. Brookhart, Organometallics 2001, 20, 3217-3219; h) J. C. Jenkins, M. Brookhart, J. Am. Chem. Soc. 2004, 126, 5827-5842; i) A. Bastero, I. Göttker-Schnetmann, C. Röhr, S. Mecking, Adv. Synth. Catal. 2007, 349, 2307-2316; j) A. Berkefeld, S. Mecking, J. Am. Chem. Soc. 2009, 131, 1565-1574; k) A. Berkefeld, M. Drexler, H. M. Möller, S. Mecking, J. Am. Chem. Soc. 2009, 131, 12613-12622; 1) T. Rünzi, U. Trischler, P. Roesle, I. Göttker-Schnetmann, H. M. Möller, L. Caporaso, A Poater, L. Cavallo, S. Mecking, Organometallics 2012, 31, 83888406.

[4] a) A. Tomov, J.-P. Broyer, R. Spitz, Macromol. Symp. 2000, 150, $53-$ 58; b) F. M. Bauers, S. Mecking, Macromolecules 2001, 34, 11651171; c) F. M. Bauers, S. Mecking, Angew. Chem. 2001, 113, 3112 3115; Angew. Chem. Int. Ed. 2001, 40, 3020-3022; d) R. Soula, C. Novat, A. Tomov, R. Spitz, J. Claverie, X. Drujon, J. Malinge, T. Saudemont, Macromolecules 2001, 34, 2022-2026; e) R. Soula, B. Saillard, R. Spitz, J. Claverie, M. F. Llaurro, C. Monnet, Macromolecules 2002, 35, 1513-1523; f) E. F. Connor, T. R. Younkin, J. I. Henderson, A. W. Waltmann, R. H. Grubbs, Chem. Commun. 2003, 2272-2273; g) F. M. Bauers, M. M. Chowdhry, S. Mecking, Macromolecules 2003, 36, 6711-6715; h) F. M. Bauers, R. Thomann, S Mecking, J. Am. Chem. Soc. 2003, 125, 8838-8840; i) A. W. Waltman, T. R. Younkin, R. H. Grubbs, Organometallics 2004, 23, 5121 5123; j) L. Kolb, V. Monteil, R. Thomann, S. Mecking, Angew. Chem. 2005, 117, 433-436; Angew. Chem. Int. Ed. 2005, 44, 429432; k) P. Wehrmann, S. Mecking, Macromolecules 2006, 39, $5963-$ 5964 ; 1) P. Wehrmann, M. A. Zuideveld, R. Thomann, S. Mecking, Macromolecules 2006, 39, 5995-6002; m) I. Göttker-Schnetmann, B. Korthals, S. Mecking, J. Am. Chem. Soc. 2006, 128, 7708-7709; n) C. H. M. Weber, A. Chiche, G. Krausch, S. Rosenfeldt, M. Ballauf, L. Harnau, I. Göttker-Schnetmann, Q. Tong, S. Mecking, Nano Lett. 2007, 7, 2024-2029.

[5] Formation of $\mathrm{Ni}-\mathrm{Et}$ species was observed and investigated in Refs. [3j,3k] and in: A. Berkefeld, H. M. Möller, S. Mecking, Organometallics 2009, 28, 4048-4055.

[6] It should be noted that in Figure $2 \mathrm{~B}$, chain termination has already occurred to a minor extent (ca. 20-30\%), as can be seen by the observation of a relatively small peak of terminal ${ }^{13} \mathrm{CH}_{3}$ groups at $\delta=$ $14.47\left(\mathrm{~d},{ }^{1} J(\mathrm{C}, \mathrm{C})=32.4 \mathrm{~Hz}\right)$, which could only originate from chain release from the $(\mathrm{N}, \mathrm{O}) \mathrm{Ni}-\left({ }^{13} \mathrm{CH}_{2}{ }^{13} \mathrm{CH}_{2}\right)_{n^{-}}{ }^{12} \mathrm{CH}_{3}$ chain-carrying species 1 a by $\beta-\mathrm{H}$ transfer, with subsequent reinsertion of ${ }^{13} \mathrm{C}_{2} \mathrm{H}_{4}$ into the resulting $(\mathrm{N}, \mathrm{O}) \mathrm{Ni}-\mathrm{H}$ species.

[7] Commercial ${ }^{13} \mathrm{C}_{2} \mathrm{H}_{4}$ was found to contain minor impurities of ${ }^{13} \mathrm{C}$-enriched ethane, butene-1, $Z$-butene-2, and $E$-butene-2 (1-2\% each impurity). However, under our NMR polymerization conditions, the presence of 1- or 2-butenes did not contribute to the formation of polymers with B2 or B1 branches: even at virtually complete ethylene consumption, no changes of the concentrations of butenes were detected by ${ }^{13} \mathrm{C}$ NMR spectroscopic analysis.

[8] a) K. E. Schwarzhans, Angew. Chem. 1970, 82, 975-982; Angew. Chem. Int. Ed. Engl. 1970, 9, 946-953; b) C. Belle, C. Bougault, M. T. Averbuch, A. Durif, J. L. Pierre, J. M. Latour, L. Le Pape, J. Am. Chem. Soc. 2001, 123, 8053-8066; c) P. Roquette, A. Maronna, M. Reinmuth, E. Kaifer, M. Enders, H. J. Himmel, Inorg. Chem. 
2011, 50, 1942-1955; d) R. H. Holm, C. J. Hawkins, in NMR of Paramagnetic Molecules: Principles and Applications (Ed.: G. N. La Mar), Academic Press, New York, 1973, pp. 243-332.

[9] a) J. P. Jesson, in NMR of Paramagnetic Molecules: Principles and Applications (Ed.: G. N. La Mar), Academic Press, New York, 1973, pp. $2-52$; b) T. J. Swift, in NMR of Paramagnetic Molecules: Principles and Applications (Ed.: G. N. La Mar), Academic Press, New York, 1973, pp. 53-83.

[10] a) We can rule out the formation of $\left[(\mathrm{N}, \mathrm{O})_{2} \mathrm{Ni}\right](\mathbf{1})$ through reaction of $(\mathrm{N}, \mathrm{O}) \mathrm{H}$ with the presumably unstable $[(\mathrm{N}, \mathrm{O}) \mathrm{Ni}(\mathrm{H})]$, because 1$)$ the latter is present in low concentrations and 2) such reaction should lead to the evolution of $\mathrm{H}_{2}$ (which was never detected by NMR spectroscopic analysis in our samples). On the contrary, the formation of 1c was accompanied by an increase of ethane $(\delta=$ $0.85 \mathrm{ppm}$ ) concentration, in agreement with Scheme S1 in the Supporting Information. b) The nature of "soluble Ni" is not entirely clear. One possibility could be that the resulting $\mathrm{Ni}(0)$ could, due to its propensity to complete its outer shell to the 18 valence electrons configuration (like in $\left.\left[\mathrm{Ni}(\mathrm{CO})_{4}\right]\right)$, form a soluble $\left[\mathrm{Ni}(\mathrm{Py})_{4}\right]$ complex upon reaction with dissolved pyridine, faster than aggregation to metallic Ni particles occurs.

[11] a) J. C. Randall, J. Macromol. Sci., Rev. Macromol. Chem. Phys. 1989, C29, 201-317; b) A. G. Ibragimov, L. O. Khafizova, I. V. Zagrebel'naya, L. V. Parfenova, R. M. Sultanov, L. M. Khalilov, U. M. Dzhemilev, Russ. Chem. Bull. 2001, 50, 292-296; c) A. Yanagisawa,
S. Habaue, K. Yasue, H. Yamamoto, J. Am. Chem. Soc. 1994, 116 6130-6141; d) D. C. Bugada, A. Rudin, Eur. Polym. J. 1987, 23, 809-818; e) G. B. Galland, R. F. de Souza, R. S. Mauler, F. F. Nunes, Macromolecules 1999, 32, 1620-1625.

[12] a) S. J. Gibbs, C. S. Johnson Jr. , J. Magn. Reson. 1991, 93, 395-402; b) dstegp3s1d pulse sequence: D. Wu, A. Chen, C. S. Johnson Jr. , $J$. Magn. Res. A. 1995, 115, 260-264; c) R. Kerssebaum, G. E. Salnikov, DOSY and Diffusion by N, A tutorial for Topspin 2.0., Version 2.0.0, Bruker BioSpin, Rheinstetten, 2006.

[13] a) S. Beck, H. H. Brintzinger, Chem. Commun. 1999, 2477-2478 b) D. E. Babushkin, H. H. Brintzinger, J. Am. Chem. Soc. 2002, 124, 12869-12873; c) C. Zuccaccia, N. G. Stahl, A. Macchioni, M. C Chen, J. A. Roberts, T. J. Marks, J. Am. Chem. Soc. 2004, 126, 1448 1464; d) C. Alonso-Moreno, S. J. Lancaster, C. Zuccaccia, A. Macchioni, M. Bochmann, J. Am. Chem. Soc. 2007, 129, 9282-9283; e) C. Alonso-Moreno, S. J. Lancaster, J. A. Wright, D. L. Hughes, C Zuccaccia, A. Correa, A. Macchioni, L. Cavallo, M. Bochmann, Organometallics 2008, 27, 5474-5487; f) L. Rocchigiani, C. Zuccaccia, D. Zuccaccia, A. Macchioni, Chem. Eur. J. 2008, 14, 6589-6592; g) G. Ciancaleoni, N. Fraldi, P. H. M. Budzelaar, V. Busico, A. Macchioni, Organometallics 2011, 30, 3096-3105. 